\title{
Introducción al Tema Central \\ Cultura e imágenes en los siglos XIX y XX latinoamericanos
}

\author{
Coordinadores \\ Pablo Alvira \\ Universidad de la República \\ Georgina Torello \\ Universidad de la República
}

En la contratapa de los libros de la colección Picturing History (entre ellos el ya clásico Eyewitnessing. The Uses of Images as Historical Evidence, de Peter Burke), lanzada en 1995 por Reaktion Books, los editores presentaban la serie como «una nueva forma de escribir historia en la que las imágenes constituyen una parte integral [...] poniendo de relieve su capacidad como herramienta activa de negociación, parodia y resistencia, como espacio en el que la historia se hace, se pone en marcha y se registra». ${ }^{1}$ Tal expresión de optimismo, no en las imágenes per se, sino en nuestra capacidad para utilizarlas, estaba justificada en tanto la disciplina parecía superar décadas de actitudes refractarias. Esa desconfianza cuando no franco desinterés- por parte de los historiadores profesionales hizo que, durante mucho tiempo, el análisis histórico de las imágenes haya sido emprendido o bien por fuera o bien en los márgenes de una disciplina mayormente abocada a la historia política.

Antes que nada, fue asunto de lo que Peter Burke ha denominado la «historia cultural clásica», en tanto se ocupó de un canon de obras maestras. Esta tradición, en la que se destacan especialmente el suizo Jacob Burckhardt y el

\footnotetext{
${ }^{1}$ En inglés en el original, traducción propia. La serie fue editada por Peter Burke, Sander L. Gilman, Ludmilla Jordanova y Roy Porter.
} 
holandés Johan Huizinga, se desplegó durante el siglo XIX y parte del XX. ${ }^{2} \mathrm{Y}$ si bien su objeto eran las imágenes en cuanto obras artísticas, volúmenes como la luminosa El otoño de la Edad Media se diferenciaban de trabajos contemporáneos especializados en la historia del arte, de la literatura, de la música - que privilegiaban la función estética de las obras- en que buscaban generalizaciones a partir de relacionar las distintas artes y a estas con la sociedad que las producía. Buscaban, en síntesis, la conexión con el espíritu de la época. En el período de entreguerras, Aby Warburg, un pensador alemán original y fuera del mundo académico, fue un paso más allá interesándose en los esquemas de percepción, fórmulas culturales vistas en el largo plazo, de gran influencia en la historia cultural posterior y en los estudios visuales. 3 Por otros caminos teóricos, esa preocupación contextual a la hora de analizar las imágenes se afianzó en lo que se conoce como historia social del arte, varios de ellos de base marxista como Frederick Antal y Arnold Hauser. ${ }^{4}$ Todas estas contribuciones, tan influyentes como heterogéneas, se centraron no obstante en el estudio de la gran tradición de la Cultura (con mayúsculas), la cultura heredada: «una historia cultural para y sobre las elites».5

En los años sesenta y setenta del siglo xx, la historiografía occidental sufrió una serie de transformaciones profundas: una «nueva historia» que irradiaba principalmente desde Francia, Inglaterra y Estados Unidos - y que resonó pronto en América Latina, aunque en forma desigual- amplió de forma significativa sus intereses y enfoques, y con ello las fuentes. Bajo el impulso de la historia de las mentalidades de impronta annaliste y del marxismo británico (en dos de sus vertientes, historia desde abajo y estudios culturales) la práctica de la disciplina fue incorporando lenta, pero decididamente las imágenes, junto a otros artefactos

\footnotetext{
${ }^{2}$ Véase, por ejemplo, Burckhardt, Jacob. La cultura del renacimiento en Italia, Tres Cantos, Akal, 2004 [1860]; y Huizinga, Johan. El otoño de la Edad Media, Madrid, Alianza, 2007 [1919].

${ }^{3}$ Por ejemplo, su libro El renacimiento del paganismo: aportaciones a la historia cultural del Renacimiento europeo, Madrid, Alianza, 2005 [1932]. La importancia de Warburg no radica sólo en sus textos, sino en su rol de organizador de la Biblioteca de Hamburgo en 1926 (Instituto Warburg a partir de 1944, en Londres), que nucleó a otros importantes investigadores como Erwin Panofsky, Ernest Cassirer o, más adelante, Ernst Gombrich. Sobre el legado del Instituto, véase el texto de Carlo Ginzburg, «De A. Warburg a E. H. Gombrich. Notas sobre un problema de método», en Mitos, emblemas, indicios, Barcelona, Gedisa, 1994.

${ }^{4}$ Véase Hauser, Arnold. Historia social de la literatura y el arte, Madrid, Guadarrama, 1978 [1951].

${ }^{5}$ Burke, Peter. Formas de historia cultural, Madrid, Alianza, 2000. p. 238.
} 
culturales, al arsenal heurístico del historiador. ${ }^{6}$ A partir de los años ochenta, una nueva historia cultural - cuya idea amplia de cultura o «culturas» debe mucho a la antropología - se consolidaba y expandía al punto de abarcar los temas más diversos imaginables. En esta apertura a otros horizontes teóricos y metodológicos, la historia cultural se encontró también con los Estudios Visuales, que surgidos y emancipados de la historia del arte comenzaban a desplegar sus investigaciones en torno a una «cultura visual», buscando «reestablecer otros acercamientos a la imagen involucrando percepciones, efectos sociales, artefactos y demás dispositivos que nos permitan anclar sentidos amplios y abarcativos.»7

Aunque no exenta de tensiones y recriminaciones mutuas, esta convergencia favoreció un enfoque donde las imágenes son consideradas tanto en su condición de artefactos como de prácticas culturales, revitalizándose de esa manera el estudio de las artes visuales tradicionales e incorporándose el análisis de otros textos icónicos antes considerados secundarios o incluso irrelevantes para la construcción de conocimiento. En ese trayecto, se pasó de una historia de las imágenes a una historia desde o a partir de las imágenes. Su análisis puede traer luz sobre amplias zonas de la vida social, aportando valiosa información sobre cultura material y universos simbólicos. La cuestión de las imágenes y su estatuto documental, no obstante, no acaba allí. En este proceso, se volvió evidente que no son solo depósito de información de una vez y para siempre, que nada más debe ser descubierta o interpretada, sino que las imágenes sufren desplazamientos de sentido en el espacio y el tiempo, por lo que es necesario ir más allá de las circunstancias de su producción y atender también a la circulación y a los usos/apropiaciones de las imágenes. Son, en este sentido, mutantes: productos culturales cuya historicidad puede y debe ser analizada en diferentes niveles.

\footnotetext{
${ }^{6}$ Véase para el caso francés Ferro, Marc. «Société du XXe siècle et histoire cinématographique», Annales E. S. C., n. ${ }^{\circ} 23$; para el británico, Samuel, Raphael. Theatres of Memory, Londres, Verso, 1994.

${ }^{7}$ Lucero, María Elena. Políticas de las imágenes en la cultura visual latinoamericana: mediaciones, dinámicas e impactos estéticos. Rosario, UNR Editora, 2017, p. 13. Sobre Estudios Visuales y cultura visual, véase dos libros centrales: el fundacional Iconology: image, text, ideology (University of Chicago Press, 2013 [1986]) de W.J. T. Mitchell, y el más reciente Visual time: The image in history (Duke University Press, 2013) de Keith Moxey. Una revisión sobre Latinoamérica en Capasso, Verónica. "Estudios visuales: aportes y notas para pensar el presente", El Ornitorrinco Tachado: Revista de Artes Visuales, 2020, no 12.
} 
En nuestro continente, desde las guerras de independencia la producción y circulación de imágenes se vinculó, de distintas maneras, con la construcción de los estados-nación y las disputas simbólicas que acarreó ese conflictivo y multidimensional proceso. Ya sea con sus pintores y arquitectos, desde las noveles instituciones estatales o a través de la prensa, las elites decimonónicas fabricaron imágenes alusivas a la «organización nacional», no sin que se infiltraran representaciones de las exclusiones y los sometimientos. Ya en el siglo XX, la irrupción en la escena pública de las clases subalternas y la emergencia de la llamada cultura de masas condujo a vínculos mucho más profusos entre las imágenes y los procesos sociopolíticos. En su heterogeneidad, y a lo largo de todo el continente, las imágenes ayudaron a construir y difundir imaginarios, dieron cuenta de las condiciones de vida, proporcionaron entretenimiento, fueron herramientas de confrontación y propaganda. En síntesis, reconstruyeron pasados, retrataron presentes e imaginaron futuros.

La historiografía latinoamericana contemporánea ha explorado $y$ problematizado esos entre vínculos cultura, imagen e historia a través de la incorporación de nuevas fuentes, enfrentándose a renovados desafíos conceptuales y metodológicos y apostando a miradas interdisciplinarias. En este sentido, en el dossier confluyen trabajos que son bien representativos del estado actual de los estudios. Los nueve textos reunidos aquí abordan distintos materiales visuales: arquitectura efímera, ilustraciones satíricas, fotografía de prensa, cine, postales, folletos. Sus miradas, básicamente historiográficas, se alimentan de una enriquecedora discusión con la sociología, la crítica literaria, los estudios de género, la arquitectura, la ciencia política y los estudios culturales. De igual manera, el conjunto de contribuciones comprende un amplio marco temporal, que va desde las alegorías de la nación de mediados del siglo XIX hasta las politizadas imágenes producidas por el cine militante en los años sesenta y setenta del siglo pasado.

Los dos primeros artículos del dossier abordan las fiestas conmemorativas, que operaron como un instrumento central en el proceso de construcción de la nacionalidad en América Latina. El artículo de Andrea Antuña aborda la organización de las fiestas patrias en Montevideo durante la segunda mitad del siglo XIX. No lo hace centrándose en las elites, sino indagando 
en la participación de otros actores: talleres de carpintería y pintura, artistas, artesanos y obreros que contribuyeron con su trabajo a la puesta en escena de estas fiestas. La autora trasciende el simple antagonismo entre elites gobernantes y gobernados, problematizando inclusive esa red generada por los intercambios y las prácticas colectivas en torno a las celebraciones. Según la autora, las decoraciones, arcos triunfales, esculturas, la representaciones y fechas elegidas para cada fiesta fueron espejo de un proceso de conformación de identidad nacional en el que las comunidades extranjeras, y los artesanos de diferentes disciplinas, entre ellos varias figuras femeninas, tuvieron un rol preponderante detrás de bambalinas. Entre los dos extremos de su periodización (1858-1894), la ciudad se transformó en términos urbanísticos, demográficos y tecnológicos, al tiempo que se convirtió en espacio de interacción social - no exenta de negociaciones, tensiones y hostilidades - en la cual a través de la experiencia de la fiesta nacional se fueron construyendo los relatos de nación. Daniela Tomeo propone en su artículo un acercamiento a las relaciones entre imagen y nación, a mediados del siglo XIX, a través del análisis de la producción caligráfica de Pablo Nin y González y su construcción de un imaginario nacional con presencia adentro y fuera de la República. De su artículo, emerge el rol fundamental de las Exposiciones Universales como difusoras de objetos simbólicos «representativos» $\mathrm{y}$, en concreto de piezas caligráficas, iniciadas en 1855, con los envíos de Juan Manuel Besnes e Irigoyen. La autora rastrea esa tradición siguiendo la obra de Nin y González, enviada a la Exposición Universal de París, de 1867, y más tarde a otras, donde fue exhibida como representante de la nación, tanto por sus contenidos visuales como por el despliegue técnico, considerado en la época una de las tradiciones gloriosas de la patria, señala Tomeo. El artículo ahonda no solo en la recepción de la obra, sino en su colocación problemática en eventos de esa magnitud que establecían jerarquías precisas para los objetos simbólicos presentados. Este estudio de caso evidencia las dinámicas de legitimación de la imagen involucradas no solo en la segunda mitad del siglo XIX, sino inclusive en pleno siglo XXI.

El artículo de Matías Borba se centra en las imágenes producidas por la prensa de guerra paraguaya durante la Guerra de la Triple Alianza (1864-1870). Varios autores utilizan la expresión guerra de papel para referirse a una de las 
dimensiones del conflicto, en tanto el enfrentamiento se desarrolló con virulencia en la prensa de los cuatro países involucrados en el evento bélico. El Gobierno paraguayo en particular apeló a la prensa satírica como propaganda en contra de los Aliados e instrumento para elevar la moral de la tropa. Interesado especialmente en examinar las imágenes del concepto de república, Borba analiza dos de los cuatro periódicos de trinchera paraguayos que se editaron, Cabichuí (1867-1868) y El Centinela (1867-1868), caracterizados por estar escritos en lengua guaraní. La defensa de la causa republicana enarbolada por el gobierno, se representa tanto a través de la letra como de las imágenes (xilograbados) en los que se instaura, siguiendo modelos europeos, franceses en particular, un mensaje en clave fundamentalmente alegórica. Una alegoría, cargada de simbología autóctona, reconocible con claridad por la tropa, y funcional al mensaje antagónico entre el Paraguay democrático, el Brasil imperial y las naciones de Argentina y Uruguay, traidoras (si pensadas en relación con los gobernantes Mitre y Flores) o víctimas (si pensadas como pueblo sometido a aquellos).

Claudia Román presenta un análisis comparativo de las estrategias visuales con que dos importantes semanarios satíricos ilustrados porteños abordaron los sucesos de la crisis económica de 1890 y de la insurrección del partido Unión Cívica, en Buenos Aires. La autora propone que más allá de los posicionamientos ideológicos de cada medio, ubicados en polos opuestos del conflicto, estos eventos impulsaron saltos cualitativos y divergentes en sus posibilidades técnicas y expresivas. A fines del siglo XIX, a las puertas de lo que sería una significativa transformación del sistema de la prensa argentino -en su aspecto noticioso, en sus alcances masivos a través del uso extensivo de nuevas tecnologías y en la ampliación del público lector- Román observa los experimentos que la crisis de 1890 suscitó en cada semanario como avances sobre los nuevos y complejos entramados de palabras e imágenes que dominarían, muy poco después, la puesta en página de los modernos magazine y de los diarios modernizados.

También las imágenes vehiculizadas por la prensa escrita son objeto de los siguientes artículos. Desde publicaciones de difusión masiva Antonella Bertolotto analiza la pelea del siglo, como se llamó al combate de boxeo entre 
el argentino Luis Ángel Firpo y el estadounidense Jack Dempsey en la Nueva York de 1923. La hipótesis afirma que la prensa escrita, a partir de uno de los eventos deportivos más importantes de la década del veinte, utilizó las imágenes como práctica para lograr producir, representar y potenciar ciertos sentidos e imaginarios sobre la masculinidad y la nacionalidad, y trata, en concreto, varios medios de prensa, especialmente Caras y Caretas, Fray Mocho, La Época y Crítica, que hicieron un uso significativo de las imágenes. El auge de esta prensa masiva, además, converge en los años veinte con la expansión de algunas prácticas deportivas y la incorporación del país a un sistema internacional de competencias y brindan un nuevo espacio público de espectáculo y de consumo. Un nuevo espacio para la libre producción, transmisión y circulación de somatotipos y morfologías corporales, gestos, conductas, hábitos y sensibilidades, que refuerzan y modelan cierta estética en los cuerpos masculinos y femeninos, desarrollando una masculinidad moderna y hegemónica. A su vez, este espacio posibilita el despliegue de narrativas heroicas y caballerescas, delimitando lo propio y ajeno, lo nacional y extranjero. El texto de Susana Delgado, mientras tanto, desde un abordaje teórico que se ubica en la intersección entre los estudios visuales y los de género, se focaliza en el análisis de fotografías de mujeres del diario La Prensa, presentadas en un suplemento dominical sobre la temporada de verano en Mar del Plata, entre 1929 y 1934. Delgado revisa esas fotografías, intentando deshilvanar las tramas que conjugan determinados imaginarios, conectando conceptos como patriarcado-feminidadimagen-imaginación e imaginario, nos permite destejer una red configurada por la producción, circulación y consumo de un sistema representativo que organiza e instituye un imaginario social determinado.

Con un decidido énfasis en la superación de los marcos nacionales, y una ampliación del marco temporal, el artículo de Inés Yujnovsky estudia la iconografía relacionada con dos espacios latinoamericanos de temprano interés turístico, las ciudades de Panamá y de Cuba, durante la primera mitad del siglo $\mathrm{xx}$. La autora se acerca a objetos visuales tales como postales, folletos, menús, tickets realizados por compañías navieras y empresas turísticas, en general llamados materiales efimeros, pero que los viajeros y viajeras guardaban como recuerdos, para analizar las representaciones de la temporalidad en la definición 
de esos imaginarios. Las ruinas, el pasado hispánico colonial, la contraposición entre pasado y presente como tópicos que se repetían a la hora de promover aventura y romance en los viajes de placer, pero que también, propone Yujnovsky, generaron una distancia espacio temporal que ubicaba en una condición de lejanía y subordinación a los países latinoamericanos.

Las relaciones entre historia, literatura e imágenes son exploradas por Federico Gerhardt en un texto que estudia la revista Saber Vivir, publicada en Buenos Aires por el diplomático chileno José Eyzaguirre, entre 1940 y 1956. Gerhardt analiza las diversas imágenes que formaban parte del contexto de la revista -incluyendo las ilustraciones y fotografías que los acompañaban, las reproducciones de documentos y los retratos de los autores- que reunió a varias de las más importantes firmas del campo literario y artístico del medio siglo argentino. Saber Vivir desarrolló un programa de orientación del consumo cultural, en términos amplios, dentro del cual la literatura ocupaba un lugar fundamental, a través de la publicación de diversos textos literarios y críticos, combinados con un uso, como se deduce del artículo, estratégico de las imágenes.

Finalmente, Isabel Wschebor explora el fenómeno cinematográfico en Uruguay a mediados de los años sesenta, cuando parecía evidenciarse el aumento de la producción cinematográfica en el país y la ampliación de sus formas de circulación a nivel local y regional. Explora escenarios en los cuales emerge la cuestión de un cine nacional como tema de debate en la agenda pública. Así, analiza un conflicto asociado al boicot de la empresa internacional Motion Pictures, para la distribución de estrenos norteamericanos en Uruguay, el impacto multidimensional del ingreso de la televisión, con las nuevas formas y prácticas de producción que acompañaron su desarrollo y, por último, explora los cambios en las instituciones abocadas a la conservación del cine en el país, junto con la discusión de cuál debía ser el cine a conservar. La búsqueda de fondo se relaciona con identificar las diferentes etapas del proceso de patrimonialización del cine en Uruguay.

En suma, este dossier presenta un panorama heterogéneo - pero en todos los casos vertebrado alrededor de eventos clave o transformaciones sociales profundas del continente latinoamericano-, donde la imagen, en su más variada 
morfología, no solo ayudó, adornó y hasta falseó la construcción de hechos históricos, sino que, en ocasiones, los moldeó o pergeñó, resaltando una vez más cuán crucial es la producción iconográfica entre los documentos que los investigadores deben interrogar. Y aún más a partir de la aparición de los medios masivos, visuales y audiovisuales, con aquella vertiginosa producción y difusión de imágenes que hoy en día ha llegado a niveles inéditos y avasallantes de saturación, pero no por esto menos significativos.» 